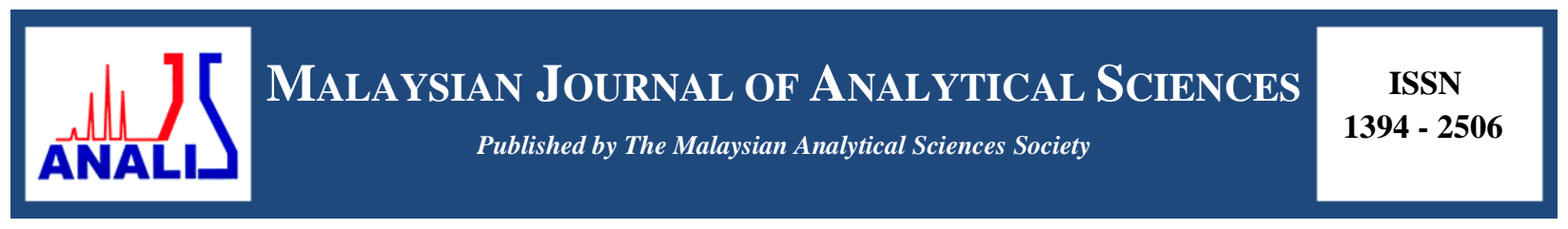

\title{
RESISTANCE OF NATIVE BACTERIA ISOLATED FROM ACTIVATED SLUDGE TOWARDS IRON AND MANGANESE
}

\author{
(Ketahanan Pencilan Bakteria Asli daripada Enapcemar Teraktif terhadap Ferum dan Mangan) \\ Nuratiqah Marsidi ${ }^{1}$, Hassimi Abu Hasan ${ }^{1} *$, Mohd Izuan Effendi Halmi ${ }^{2}$, Siti Rozaimah Sheikh Abdullah ${ }^{1}$ \\ ${ }^{I}$ Chemical Engineering Program, Research Centre for Sustainable Process Technology (CESPRO), \\ Faculty of Engineering and Built Environment, \\ Universiti Kebangsaan Malaysia, 43600 UKM Bangi, Selangor, Malaysia \\ ${ }^{2}$ Department of Land Management, Faculty of Agriculture, \\ Universiti Putra Malaysia, 43400 Serdang, Selangor. Malaysia \\ *Corresponding author: hassimi@ukm.edu.my
}

Received: 13 April 2017; Accepted: 17 April 2018

\begin{abstract}
A study was conducted to observe the resistance of native isolated bacteria towards selected heavy metals (iron; Fe and manganese; $\mathrm{Mn}$ ) in a separate exposure. Isolated bacteria were evaluated by culturing them in nutrient broth medium that contained approximately $3 \times 10^{6} \mathrm{CFU} / \mathrm{mL}$ bacteria with different initial concentrations $(0,50,100$ and $200 \mathrm{mg} / \mathrm{L})$. Result showed that a plate with bacterial growth indicated bacterial resistance, which was verified based on CFU/mL. At $0 \mathrm{mg} / \mathrm{L}$, bacteria grew well on the plate with $\mathrm{Fe}$ and Mn. The bacterial number began to decrease at 50 and $100 \mathrm{mg} / \mathrm{L}$ for Fe and at $200 \mathrm{mg} / \mathrm{L}$ for Mn. Only a few colonies survived (isolate AM2) the toxicity of high Fe amount; the isolated bacteria almost showed no growth along the plate. AM2, AM3 and AM4 presented resistance to Mn until $200 \mathrm{mg} / \mathrm{L}$, but not AM6. The bacteria showed no growth at 100 and $200 \mathrm{mg} / \mathrm{L}$. Thus, the Fe and Mn concentrations that can be applied during acclimatisation ranged from $0 \mathrm{mg} / \mathrm{L}$ to $200 \mathrm{mg} / \mathrm{L}$ with isolated AM2 and AM4 for Fe and Mn removal.
\end{abstract}

Keywords: biosorption, drinking water resources, iron, manganese, resistance bacteria

\begin{abstract}
Abstrak
Satu kajian telah dijalankan untuk melihat tahap ketahanan bakteria tempatan terhadap logam berat terpilih (ferum; Fe dan mangan; Mn) dalam pendedahan berasingan. Bakteria telah diuji dengan pengkulturan dalam medium kaldu nutrien mengandungi kira-kira $3 \times 10^{6} \mathrm{CFU} / \mathrm{mL}$ bakteria dengan kepekatan logam berat yang berbeza $(0,50,100 \mathrm{and} 200 \mathrm{mg} / \mathrm{L})$. Sebagai keputusan, plat yang mempunyai pertumbuhan bakteria menunjukkan bahawa bakteria merintang kepada kepekatan masingmasing dan disahkan berasaskan unit pembentukan koloni per $\mathrm{mL}$. Pada $0 \mathrm{mg} / \mathrm{L}$, bakteria tumbuh di sepanjang plat yang mengandungi Fe dan Mn. Bilangan CFU/mL mula untuk berkurang pada 50 dan $100 \mathrm{mg} / \mathrm{L}$ bagi Fe manakala pada $200 \mathrm{mg} / \mathrm{L}$, hanya beberapa koloni bertahan (pencilan AM2) disebabkan ketoksikan oleh Fe yang berkepekatan tinggi and hampir kesemua pencilan bakteria menunjukkan tiada pertumbuhan sepanjang plat. Bagi mangan, kesemua bakteria terpilih AM2, AM3 dan AM4 masih memberikan bilangan CFU/mL sehingga kepekatan $200 \mathrm{mg} / \mathrm{L}$ kecuali AM6, bakteria tidak menunjukkan pertumbuhan pada 100 dan $200 \mathrm{mg} / \mathrm{L}$. Oleh itu, julat Fe dan Mn yang boleh diaplikasikan dalam penyesuaian bakteria ialah dari 0 hingga 200 mg/L dengan pencilan AM2 dan AM4 adalah untuk penyingkiran Fe dan Mn.
\end{abstract}

Kata kunci: biojerapan, besi, mangan, sumber air minuman, ketahanan bakteria 


\section{Introduction}

Numerous treatment types are used in industries to remove heavy metals, such as cadmium, nickel, iron, plumbum, chromium and arsenic, from wastewater. Conventional treatment technologies for heavy metals include precipitation, electrocoagulation, filtration and sedimentation [1]. However, the use of these technologies is limited due to their time requirement, high cost and maintenance, as well as environmental toxicity caused by chemicals added into the process. Furthermore, Ahluwalia and Goyal [2] claimed that chemical technologies can generate large volumetric sludge and increase costs. Conventional methods are also either inefficient or expensive when heavy metals exist in low concentrations [3, 4]. Hence, researchers have introduced new methods using unlimited and easily available sources, such as microorganisms and wastes, to treat wastewater that contains heavy metals.

Microorganisms in natural environment, such as bacteria, fungi, algae and yeast, can be exploited for treating heavy metal that contains large amount of wastes. Indigenous community of microorganisms from a particularly polluted area commonly exhibits the ability to thrive in extreme and toxic conditions [5]. The heavy metal uptake of biomass can be divided into two common methods, namely, bioaccumulation (active metabolic mode) and biosorption (passive metabolic mode) [6-9]. Biosorption is a quick process and independent from specific nutrients, whereas bioaccumulation is a slow and nutrient-dependent process [10]. Non-living biomasses in biosorption are typically affected with physical and chemical factors, such as $\mathrm{pH}$, temperature, biomass and heavy metal concentration in a solution.

The present study aims to determine the range of $\mathrm{Fe}$ and manganese concentrations that can affect the survival of native bacteria after exposure. In addition, possible potential of bacteria to uptake the metals were also investigated. The present result can be used for the isolation, identification, acclimatisation and treatment of bacteria in the future.

\section{Source of activated sludge}

\section{Materials and Methods}

Sample was collected from a domestic sewage in Bukit Puteri residence, Universiti Kebangsaan Malaysia. This waste was generated by more than 100 households whose toilets and kitchens were channelled into the sedimentation tank. The raw sewage, which was stored at $4{ }^{\circ} \mathrm{C}$ until usage, was a dark green sludge $(\mathrm{pH}$ 6.5) that consisted mainly of $95 \%$ water. Figure 1 shows the sequence of activated sludge collection, which was according to Nye method [11]. The activated sludge characteristics are listed in Table 1.
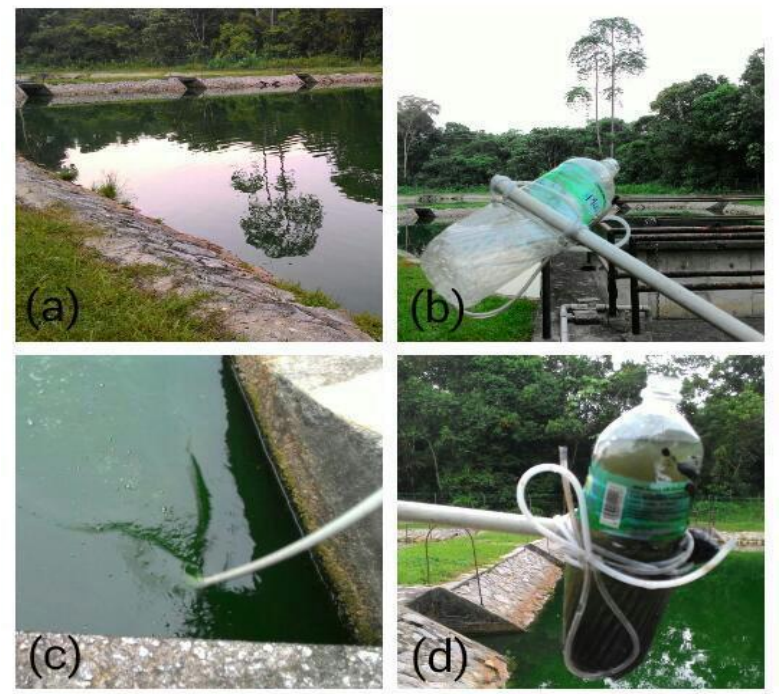

Figure 1. (a) Oxidation point at a residential area, (b) sampling bottle, (c) sampling point and (d) sample collection 


\section{Media preparation}

$\mathrm{Fe}(\mathrm{III})$ chloride hexahydrate $\left(\mathrm{FeCl}_{3} 6 \mathrm{H}_{2} \mathrm{O}\right)$ and $\mathrm{Mn}(\mathrm{II})$ chloride $\left(\mathrm{MnCl}_{2} .4 \mathrm{H}_{2} \mathrm{O}\right)$ were the metal salts used to prepare the stock solution of metal ions in aqueous form. A stock solution was separately prepared for each of the metal ions by dissolving $1 \mathrm{~g}$ of the metal salts in $1000 \mathrm{~mL}$ of distilled water $(1000 \mathrm{mg} / \mathrm{L})$. The solutions were prepared using a volumetric flask. The concentration range used was prepared by serial dilution of the stock solution using deionised water [12]. The nutrient broth (NB) (Oxoid, Malaysia) that was used to enrich microbes consisted of yeast extract $(2.0 \mathrm{~g})$, peptone $(5.0 \mathrm{~g})$, sodium chloride $(5.0 \mathrm{~g})$ and agar $(15.0 \mathrm{~g})$ in $1 \mathrm{~L}$ of distilled water.

\section{Screening, isolation and growth of native bacteria}

Heavy metal-resistant bacterial species were isolated from the activated sludge by appropriate serial dilutions $\left(10^{-1}-\right.$ $10^{-4}$ ) using $0.85 \% \mathrm{NaCl}$ solution (Merck, Malaysia). A total of $0.1 \mathrm{~mL}$ of each dilution was spread onto a plate that contained nutrient agar (Oxoid, Malaysia) and incubated for 24 hours. These dilutions were characterised morphologically based on biochemical reactions. The isolates were maintained on a slant that contained nutrient agar. To determine the growth pattern of the isolates, one loop of a single colony was inoculated in $100 \mathrm{~mL}$ of NB medium grown in a shaker incubator at $37{ }^{\circ} \mathrm{C}$ with $150 \mathrm{rpm}$ for 24 hours. Growth pattern was determined by using a spectrophotometer (HACH, USA) after a two-hour interval by measuring optical density (OD) at $\mathrm{OD}_{550}$.

\section{Biosorption studies of Fe and Mn}

Bacteria were grown in an incubator shaker (Protech, Model SI-100D, Malaysia) at $150 \mathrm{rpm}$ and $37^{\circ} \mathrm{C}$ for 24 hours. The culture was centrifuged at $4000 \mathrm{rpm}$ for 10 minutes (Eppendorf, Centrifuge 5810, Malaysia). The supernatant was discarded, and the bacterial pellet undergone cell washing using sterile saline water and dilution until the OD of $0.6(550 \mathrm{~nm})$. Approximately $10 \%$ of inoculum was inoculated using different concentrations $(0-200 \mathrm{mg} / \mathrm{L})$ of $\mathrm{Fe}$ and $\mathrm{Mn}$ salt in $250 \mathrm{~mL}$ Erlenmeyer flask following Fadel et al. method [13]. The observation was conducted within 24 hours with four-hour interval by measuring the OD. After 24 hours, the bacteria were spread onto the nutrient agar to determine the colony-forming unit per $\mathrm{mL}(\mathrm{CFU} / \mathrm{mL})$ after exposure to $\mathrm{Fe}$ and $\mathrm{Mn}$. The experiment set-up is presented in Table 1.

Table 1. (a, b) Iron at 0 and 24 hours; (c, d) manganese at 0 and $24 \mathrm{~h}$ in triplicate

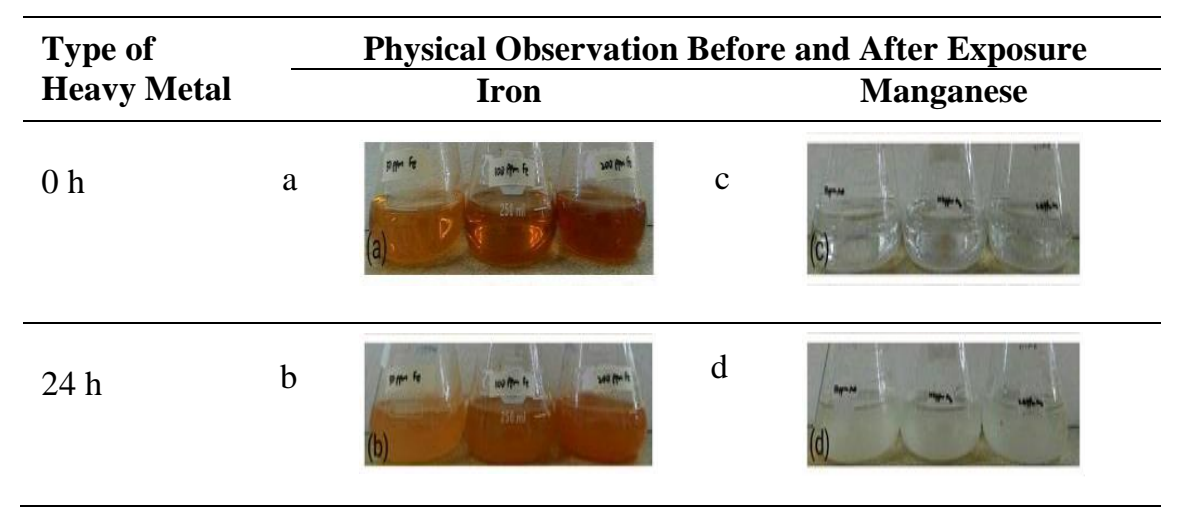

\section{Physicochemical parameters of the activated sludge}

\section{Results and Discussion}

The activated sludge from oxidation pond was analysed in terms of water quality parameters, including $\mathrm{pH}$, dissolved oxygen, total suspended solid, oxygen reduction potential and chemical oxygen demand. Table 2 shows the sample characteristics of activated sludge prior to its exposure to heavy metal. 
Table 2. Characteristics of activated sludge from the oxidation pond effluent used for heavy metal exposure

\begin{tabular}{lc}
\hline Parameter & Value \\
\hline $\mathrm{pH}$ & 6.5 \\
Total suspended solid $(\mathrm{g} / \mathrm{L})$ & 18.83 \\
Chemical oxygen demand $(\mathrm{mg} / \mathrm{L})$ & 6000 \\
Oxygen reduction potential $(\mathrm{mV})$ & -67.5 \\
Dissolved oxygen $(\mathrm{mg} / \mathrm{L})$ & 1.86 \\
\hline
\end{tabular}

\section{Growth patterns of native bacteria}

To screen the native bacteria obtained from the activated sludge, about 22 different bacteria were isolated through physical observation on plate agar. Gram staining was performed to determine the morphology of the respective bacteria. Among the 22 isolates, only seven isolates, namely, AM1, AM2, AM3, AM4, AM5, AM6 and AM7, showed different microscopic views. Most of the bacterial isolates were rod-shaped, chained and gram positive. Culturing of the isolated bacteria reduced the number of isolates to four, namely, AM2, AM3, AM4 and AM6 because the three other isolates experienced a slow growth, as shown in Figure 2. To illustrate the bacterial growth, the growth curve of each of the four isolates is displayed in Figure 3.

\begin{tabular}{|c|c|c|c|c|}
\hline Type of Bacteria & AM2 & AM3 & AM4 & AM6 \\
\hline Streak plate & & & & \\
\hline Single colony & & & $\%$ & \\
\hline
\end{tabular}

Figure 2. Four selected isolates, namely, AM2, AM3, AM4 and AM6

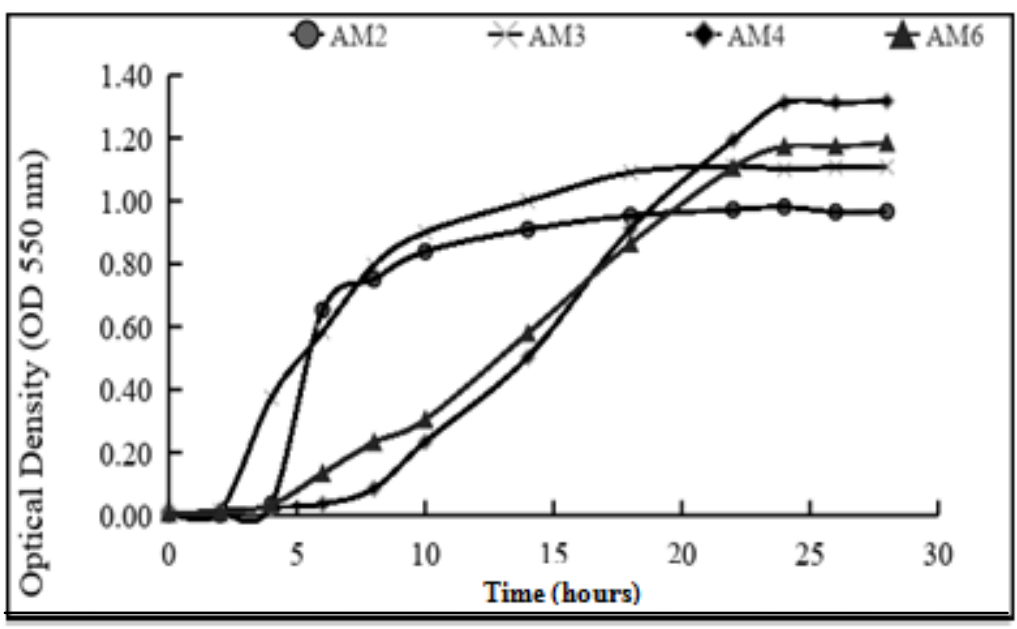

Figure 3. Growth curved of the four selected isolates (AM2, AM3, AM4 and AM6). AM2 and AM3 showed rapid growth, whereas AM4 and AM6 exhibited slow growth within 28 hours 


\section{Biosorption of Fe and Mn}

The effects of Fe and Mn were determined based on CFU/mL. After 24 hours of exposure, samples were diluted to $10^{-1}$ and plated on nutrient agar for another 24 hours of incubation. The bacterial colonies were counted, and data are presented in Figure 4. Evaluation was performed using three different Fe concentrations, namely, 50, 100 and $200 \mathrm{mg} / \mathrm{L}$. On average, AM2 showed increment in the number of bacterial colonies, with the highest number of bacterial colony of $2 \times 10^{3} \mathrm{CFU} / \mathrm{mL}$ at $200 \mathrm{mg} / \mathrm{L}$ plate. However, AM3 and AM6 only demonstrated bacterial growth at $50 \mathrm{mg} / \mathrm{L}$ Fe with only $9 \times 10^{2}$ and $1 \times 10^{2} \mathrm{CFU} / \mathrm{mL}$, respectively. In addition, the CFU of AM4 was only $2.5 \times 10^{2} \mathrm{CFU} / \mathrm{mL}$ at $100 \mathrm{mg} / \mathrm{L} \mathrm{Fe}$. No bacterial growth was observed for AM3 and AM6 with 100 and $200 \mathrm{mg} / \mathrm{L}$ $\mathrm{Fe}$ and for AM4 with 50 and $200 \mathrm{mg} / \mathrm{L}$ Fe. This phenomenon occurred because these bacteria (AM3, AM4 and AM6) cannot resist Fe concentration at approximately 100 and $200 \mathrm{mg} / \mathrm{L}$.

Among the four different types of bacteria, AM2 presented the highest resistance to Fe concentration to about 200 $\mathrm{m} / \mathrm{L}$. Theoretically, $\mathrm{Fe}$ is essential for growth, but it can be toxic to living cells at high concentration, as demonstrated by isolates AM3, AM4 and AM6. Fe is important for biological systems but only at definite low level [14]. Moreover, the addition of alone results in relatively unchanged bacterial growth, but the addition of glucose to Fe causes substantial increase in the rates of bacterial growth and biomass accumulation [15].

Different CFU/mL values among different bacteria may be due to the large surface area of biomass; consequently, the ability of bacteria to bind to the cell wall causes its high uptake of heavy metals $[16,17]$. Nonetheless, bacteria that can survive well in high heavy metal concentrations, such as isolate AM2, are considerably important as bioremediation agents because they can achieve different transformations and immobilisation processes [18]. Figure 4 illustrates a bar graph of the $\mathrm{CFU} / \mathrm{mL}$ values for the Mn biosorption of different types of selected isolates.

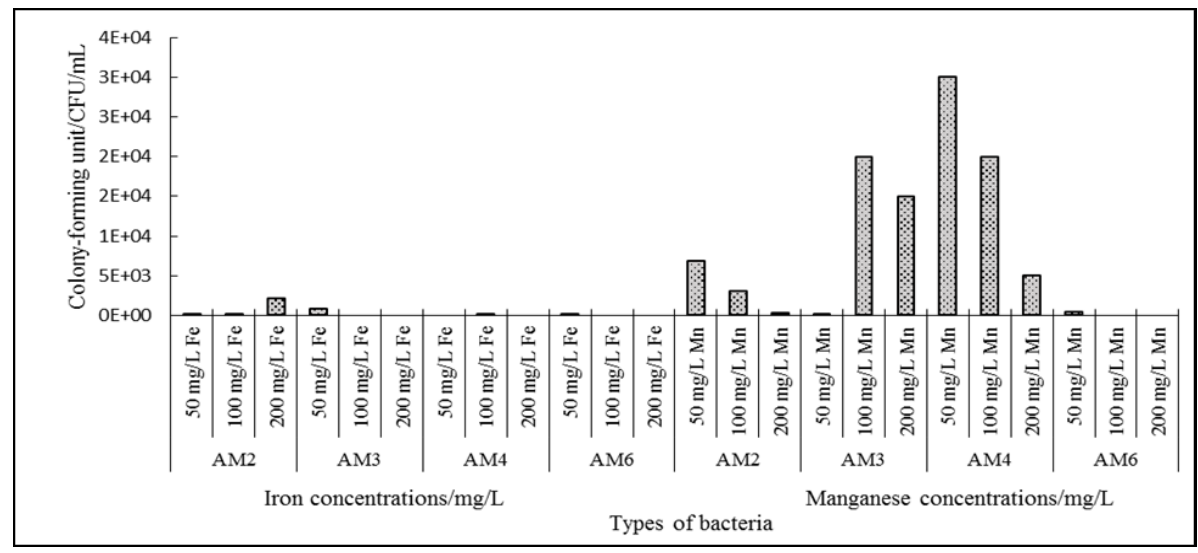

Figure 4. Colony-forming unit per $\mathrm{mL}(\mathrm{CFU} / \mathrm{mL})$ of AM2, AM3, AM4 and AM6 towards different Fe and $\mathrm{Mn}$ concentration

Mn (50, 100 and $200 \mathrm{mg} / \mathrm{L})$ biosorption showed different trends in the bar graph. The bacteria growth of AM2, $(\mathrm{CFU} / \mathrm{mL})$ steadily decreased along the experiment, with the highest bacterial growth of $6.9 \times 10^{3} \mathrm{CFU} / \mathrm{mL}$. AM3 showed fluctuation at $50 \mathrm{mg} / \mathrm{L}$ because of minimal bacterial growth; however, at 100 and $200 \mathrm{mg} / \mathrm{L}$, the CFU/mL began to increase and decrease (from $2 \times 10^{4} \mathrm{CFU} / \mathrm{mL}$ to $1.5 \times 10^{3} \mathrm{CFU} / \mathrm{mL}$ ), respectively. During the first exposure of AM4, the bacterium resisted $\mathrm{Mn}$ at $50 \mathrm{mg} / \mathrm{L}$ with $3 \times 10^{4} \mathrm{CFU} / \mathrm{mL}$. At 100 and $200 \mathrm{mg} / \mathrm{L} \mathrm{Mn}$, the bacterial colony count began to decrease to $2 \times 10^{4}$ and $5 \times 10^{3} \mathrm{CFU} / \mathrm{mL}$, respectively. AM6 only demonstrated low growth at $50 \mathrm{mg} / \mathrm{L}$ and zero growth for 100 and $200 \mathrm{mg} / \mathrm{L} \mathrm{Mn}$. Overall, most of the bacteria presented a decreasing order of resistance with increased Mn concentration. This trend was attributed to that bacteria cannot resist high $\mathrm{Mn}$ concentration, and no growth eventually occurred at the end of the exposure period. 
The microbial populations exhibited a wide spectrum of sensitivity to metal ions. Growth inhibition is a common response to heavy metal stress and an important indicator of heavy metal tolerance [19]. Growth was stimulated at low concentration. By contrast, at high metal concentration, the growth became gradually inhibited, toxic and finally terminated. These phenomena were observed in all the isolates, namely, AM2, AM3, AM4 and AM6.

\section{Conclusion}

Experimental study on resistance of native isolated bacteria from activated sludge towards $\mathrm{Fe}$ and $\mathrm{Mn}$ concluded that concentration of $\mathrm{Fe}$ and $\mathrm{Mn}$ suitable for the acclimatisation of bacteria are in the range of $0-200 \mathrm{mg} / \mathrm{L}$. Isolate $\mathrm{AM} 2$ resists $\mathrm{Fe}$ until $200 \mathrm{mg} / \mathrm{L}$. Isolate AM4 shows decreasing growth trend at $\mathrm{Mn}$ concentration ranging from 0 $\mathrm{mg} / \mathrm{L}$ to $200 \mathrm{mg} / \mathrm{L}$, indicating that it still grow but with decreasing value of number of $\mathrm{CFU} / \mathrm{mL}$ compared to other three isolates (AM2, AM3 and AM6).

\section{Acknowledgement}

The author expresses gratitude to Universiti Kebangsaan Malaysia for funding this research under grant number GUP-2017-022.

\section{References}

1. Ahluwalia, S. S. and Goyal, D. (2007). Microbial and plant derived biomass for removal of heavy metals from wastewater. Bioresource Technology, 98: 2243-2257.

2. Tangahu, B. V., Abdullah, S. R. S., Basri, H., Idris, M., Anuar, N. and Mukhlisin, M. (2011). Review on heavy metals $(\mathrm{As}, \mathrm{Pb}$ and $\mathrm{Hg}$ ) uptake by plants through phytoremediation. International Journal of Chemical Engineering, 2011: 1-31.

3. Tsekova, K., Todorova, D., Dencheva, V. and Ganeva, S. (2010). Biosorption of copper(II) and cadmium(II) from aqueous solutions by free and immobilized biomass of Aspergillus niger. Bioresource Technology, 101(6): 1727-1731.

4. Ileri, O., Cay, S., Uyanik, A. and Erduran, N. (2014). Removal of common heavy metals from aqueous solutions by waste Salvadora persica L. Branches (Miswak). International Journal of Environmental Research, 8(4): 987-996.

5. Sannasi P., Kader J., Othman, O. and Salmijah, S. (2009). Physical growth and characterization of bacterial cells exposed to $\mathrm{Cd}(\mathrm{II}), \mathrm{Cr}(\mathrm{VI}), \mathrm{Cu}(\mathrm{II}), \mathrm{Ni}(\mathrm{II})$ and $\mathrm{Pb}(\mathrm{II})$. Journal of Environment Research and Development, 4(1): 8-18.

6. Hasan, H. A., Abdullah, S. R. S., Kofli, N. T. and Kamarudin, S. K. (2010). Biosorption of manganese in drinking water by isolated bacteria. Journal of Applied Science, 10(21): 2653-2657.

7. Hasan, H. A., Abdullah, S. R. S., Kofli, N. T. and Kamarudin, S. K. (2012). Isotherm equilibriums of $\mathrm{Mn}^{2+}$ biosorption in drinking water by locally isolated Bacillus species and sewage activated sludge. Journal of Environmental Management, 111: 34-43.

8. Hasan, H. A., Abdullah, S. R. S., Kofli, N. T. and Jay, Y. S. (2016). Interaction of environmental factors on simultaneous biosorption of lead and manganese ions by locally isolated Bacillus cereus. Journal of Industrial and Engineering Chemistry, 37: 295-305.

9. Zainudin, F. M., Hasan, H. A. and Abdullah, S. R. S. (2016). Effect of initial concentrations on biosorption of manganese by locally isolated Bacillus cereus. Jurnal Kejuruteraan, 28: 73-78.

10. Kadukova, J. and Vircikova, E. (2005). Comparison of differences between copper bioaccumulation and biosorption. Environment International, 31(2): 227-232.

11. Nye, C. K. (2014). Phytoremediation of micropollutant through sub-surface constructed wetlands. Thesis of Bachelor Degree, Universiti Kebangsaan Malaysia.

12. Samarth, D. P., Chandekar, C. J. and Bhadekar, R. K. (2012). Biosorption of heavy metals from aqueous solution using Bacillus licheniformis. International Journal of Pure \& Applied Sciences \& Technology, 10(2): $12-19$.

13. Fadel, M., Hassanein, N. M., Elshafei, M. M., Mostafa, A. H., Ahmed, M. A. and Khater, H. M. (2015). Biosorption of Manganese from Groundwater by Biomass of Saccharomyces cerevisiae. HBRC Journal, 13(1): $106-113$.

14. Sorokina, E. V., Yudina, T. P., Bubnov, I. A. and Danilov, V. S. (2013). Assesment of iron toxicity using a luminescent bacterial test with an Escherichia coli recombinant strain. Microbiology, 82(4): 439-444. 
15. Church, M. J., Hutchins, D. A. and Ducklow, H. W. (2000). Limitation of bacterial growth by dissolved organic matter and iron in the Southern Ocean. Applied and Environmental Microbiology, 66(2): 455-466.

16. Gadd, G. M (1994). The Genus Aspergillus. Springer Science, Business Media, New York: 361-374.

17. Iqbal, A., Zafar, S. and Ahmad, F. (2005). Heavy metal biosorption potential of Aspergillus and Rhizopus sp. isolated from wastewater treated soil. Journal of Applied Science and Environmental Management, 9(1): 123126.

18. Ghane, M., Tabandeh, F. and Bandehpour, M. (2013). Isolation and characterization of a heavy metal resistant Comamonas sp. from industrial effluents. Iranian Journal of Science and Technology, 37(2): 173-179.

19. Malar, S., Vikram, S. S., Favas, P. J. C. and Perumal, V. (2014). Lead heavy metal toxicity induced changes on growth and antioxidative enzymes level in water hyacinths (Eichhornia crassipes (Mart.)). Botanical Studies, 55(54): $1-11$. 